\title{
Carbon Footprint Analysis of Bamboo Scrimber Flooring-Implications for Carbon Sequestration of Bamboo Forests and Its Products
}

\author{
Lei Gu ${ }^{1,2,3,4,5, *}$, Yufeng Zhou ${ }^{3,4,5,6}$, Tingting Mei ${ }^{3,4,5,6}$, Guomo Zhou ${ }^{3,4,5,6}$ and Lin Xu ${ }^{3,4,5,6}$ \\ College of Economics and Management, Zhejiang A\&F University, Lin'an 311300, China \\ Zhejiang Province Farmer Development Research Center, Zhejiang A\&F University, Lin'an 311300, China \\ State Key Laboratory of Subtropical Silviculture, Zhejiang A\&F University, Lin'an 311300, China; \\ zhouyf@zafu.edu.cn (Y.Z.); ttmei@zafu.edu.cn (T.M.); zhougm@zafu.edu.cn (G.Z.); xul1210@163.com (L.X.) \\ 4 Zhejiang Provincial Collaborative Innovation Center for Bamboo Resources and High-efficiency Utilization, \\ Zhejiang A\&F University, Lin'an 311300, China \\ 5 Key Laboratory of Carbon Cycling in Forest Ecosystems and Carbon Sequestration of Zhejiang Province, \\ Zhejiang A\&F University, Lin'an 311300, China \\ 6 School of Environmental and Resource Sciences, Zhejiang A\&F University, Lin'an 311300, China \\ * Correspondence: gulei@zafu.edu.cn; Tel.: +86-571-6374-6399
}

Received: 20 November 2018; Accepted: 10 January 2019; Published: 11 January 2019

\begin{abstract}
Bamboo forest is characterized by large carbon sequestration capability and it plays an important role in mitigating climate change and global carbon cycling. Previous studies have mostly focused on carbon cycling and carbon stocks in bamboo forest ecosystems, whereas the carbon footprints of bamboo products have not received attention. China is the largest exporting country of bamboo flooring in the world. Estimating the carbon footprint of bamboo flooring is of essential importance for the involved enterprises and consumers to evaluate their own carbon footprints. In this study, we investigated the production processes of bamboo scrimber flooring for outdoor use, a typical bamboo flooring in China. Based on business-to-business (B2B) evaluation method, we assessed $\mathrm{CO}_{2}$ emission and carbon transfer ratio in each step of the production process, including transporting bamboo culms and producing and packing the products. We found that to produce $1 \mathrm{~m}^{3}$ of bamboo scrimber flooring, direct carbon emissions from fossil fuels during transporting raw materials/semi-finished products, from power consumptions during production, and indirect emissions from applying additives were $30.94 \mathrm{~kg} \mathrm{CO}_{2}$ eq, $143.37 \mathrm{~kg} \mathrm{CO}$ eq, and $78.34 \mathrm{~kg} \mathrm{CO}_{2}$ eq, respectively. After subtracting the $267.54 \mathrm{~kg} \mathrm{CO}_{2}$ eq carbon stocks in the product from the $252.65 \mathrm{~kg}$ $\mathrm{CO}_{2}$ eq carbon emissions derived within the defined boundary, we found that the carbon footprint of $1 \mathrm{~m}^{3}$ bamboo scrimber flooring was $-14.89 \mathrm{~kg} \mathrm{CO}_{2}$ eq. Our results indicated that the bamboo scrimber flooring is a negative carbon-emission product. Finally, we discussed factors that influence the carbon footprint of the bamboo flooring and gave suggestions on carbon emission reduction during production processes. This study provided a scientific basis for estimating carbon stocks and carbon footprints of bamboo products and further expanded knowledge on carbon cycling and lifespan of carbon in the bamboo forest ecosystem.
\end{abstract}

Keywords: climate change; carbon emission reduction; bamboo floor; green-level; carbon storage

\section{Introduction}

To cope with climate change and global warming, reduction of carbon emissions is sought worldwide. Accurate estimates of carbon footprint for wood products are beneficial to both enterprises and consumers, because the carbon footprint tracks the greenhouse gases emissions during the entire 
life cycle of the wood products. The footprints help enterprises to fulfill their responsibilities to reduce emissions in a goal-oriented way; quantifying carbon emissions aids in finding ways to reduce carbon emissions during design, production, and supply stages. Consumers can search for and purchase low-carbon products or services with the guidance of carbon footprints.

To date, studies on carbon footprints have mainly focused on micro (i.e., product and individual), or macro (i.e., country and region) levels. The carbon footprints of diverse products have been assessed, including primary agricultural products (e.g., cucumber) [1], processed food products (e.g., grape wine) [2], print magazines (e.g., National Geographic) [3], and chemical engineering and mechanical products (e.g., plastic, cars, and commercially produced earthenware ceramic piece) [4-6], and forest-products used in construction [7-9]. Refs. [10-13] studied carbon footprints at different scales from national and regional perspectives. However, for most products, the process from original materials to final products involves complicated procedures, which poses two major problems in evaluating carbon footprint. The first problem is that indirect carbon emissions are more difficult to monitor than the direct emissions, and so far, the indirect carbon emissions have been ignored. The second problem is that the evaluation is based on secondary-level data (indirect measurement) but lacking initial-level data (direct measurement). Most of the previous studies have focused on consumables (e.g., furniture, ornamental earthenware ceramic pieces), forest-based products such as cork, and office paper. However, bamboo products with carbon-stock function have received less attention.

Bamboo plants include approximately 1500 species worldwide that belong to the Bambusoideae subfamily in the Gramineae family [14,15]. Bamboo forests are widely distributed in the subtropical regions of Asia, Africa, and Latin America; the 31.5 Mha bamboo forests account for approximately $0.8 \%$ of the world's total forest area [16]. China is one of the countries with the most abundant bamboo resources in the world. Over 500 bamboo species in 39 genera grow in China [17]. Moso bamboo (Phyllostachys pubescens) is widely distributed in the tropical and subtropical regions of eastern and southeastern Asia. In China, the bamboo forest area covers approximately 6 Mha, out of which 74\% represents the Moso bamboo [18]. Moreover, Moso bamboo forests have a large carbon sequestration capacity compared with Chinese fir (Cunninghamia lanceolata (Lamb.) Hook.) forests [19-21], and can be used for producing diverse products. The bamboo industry in China is well-developed and worth 192.3 billion CNY; both its output and value rank first in the world [22]. The bamboo industry has developed quickly in recent years, partially due to the flexibility and hardness of bamboo that meet the requirements of diverse products, and more importantly, due to the development of new production techniques. The demand for bamboo based products such as bamboo flooring, furniture, and chipboards for building, decoration, and other uses has increased rapidly [23]. For example, the production of bamboo flooring in China has increased from $300,000 \mathrm{~m}^{3}$ in 1998 to nearly $115,000,000 \mathrm{~m}^{3}$ in 2016 , with $60 \%-70 \%$ of them being exported and accounting for $90 \%$ of the worldwide market share [24]. The massive production raises a concern: will the fast growing, efficiently carbon-sequestrating bamboo give raise to final products that are a carbon source due to emissions from the production process? During the bamboo-to-product process, carbon sequestrated and stored in growing bamboos may be offset or even overturned by the emissions. Thus, there is a need to track the carbon emissions and evaluate the carbon footprints of bamboo products to assess whether these products are a carbon source or sink.

In this study, we investigated the entire direct and indirect carbon emissions during production processes of bamboo flooring, with initial-level data in each stage of the production and supply chain. Also, our objective is to estimate the complete carbon footprint of bamboo flooring products (carbon stocks and direct/indirect emissions) and determine whether the bamboo flooring products are a carbon source or sink in the case study in China. 


\section{Materials and Methods}

\subsection{Study Area and Objective}

The evaluated product was bamboo scrimber flooring that is made of separate or bundled bamboo strings via a series of processing procedures including drying, gluing, and thermo-fixation under high temperature and pressure. Bamboo scrimber flooring accounts for $80 \%$ of the total production of bamboo flooring in China. The flooring was made by Dasso Industrial Co. Ltd. in Hangzhou, Zhejiang, China, and Dasso's subsidiary company in Zixi, Jiangxi, China. Dasso is the largest manufacturer for producing bamboo flooring and bamboo decoration materials in China.

In this study, raw bamboos were obtained and preliminarily processed in Jiangxi province which is abundant with bamboo resources. The subsidiary company harvested bamboo culms from 4 regions (Zixi, Jinxi, Nancheng, and Lichuan in Jiangxi province), and transported them to Zixi. The average transportation distance to the preliminary processing facilities was determined to be $55 \mathrm{~km}$ (one way). Semi-finished products were transported to a subsidiary of Dasso in Hangzhou and therein further processed to bamboo scrimber flooring, and the average transportation distance was $550 \mathrm{~km}$. Out of the flooring products, we chose the $1860 \mathrm{~mm}$ long, $137 \mathrm{~mm}$ wide, and $20 \mathrm{~mm}$ thick plank of bamboo scrimber flooring for outdoor use as the studied product.

\subsection{Criteria and Boundaries for Assessment}

We adopted the methodology of "PAS2050: 2008: specification for the assessment of the life cycle greenhouse gas emissions of goods and services" compiled by British Standards Institution (BSI) as an assessment standard. Based on life cycle analysis (LCA), we chose the B2B assessment method to assess $\mathrm{CO}_{2}$ emissions and carbon stocks of products within the entire production processes, including transporting, manufacturing, packaging, and warehousing of the products.

The assessment boundaries include: (1) carbon emission from fossil fuels used for transportation of bamboo culms, semi-finished products, and additives (e.g., glue, oil paint, and cartons); (2) carbon emission from electric power used in more than 20 procedures (Figure 1) to process raw culms into semi-finished products and further into final products; (3) carbon emission from additives (glue, oil paint, and cartons); and (4) biomass carbon stocks stored in bamboo flooring products. More detailed boundary descriptions are shown below in Section 2.4.

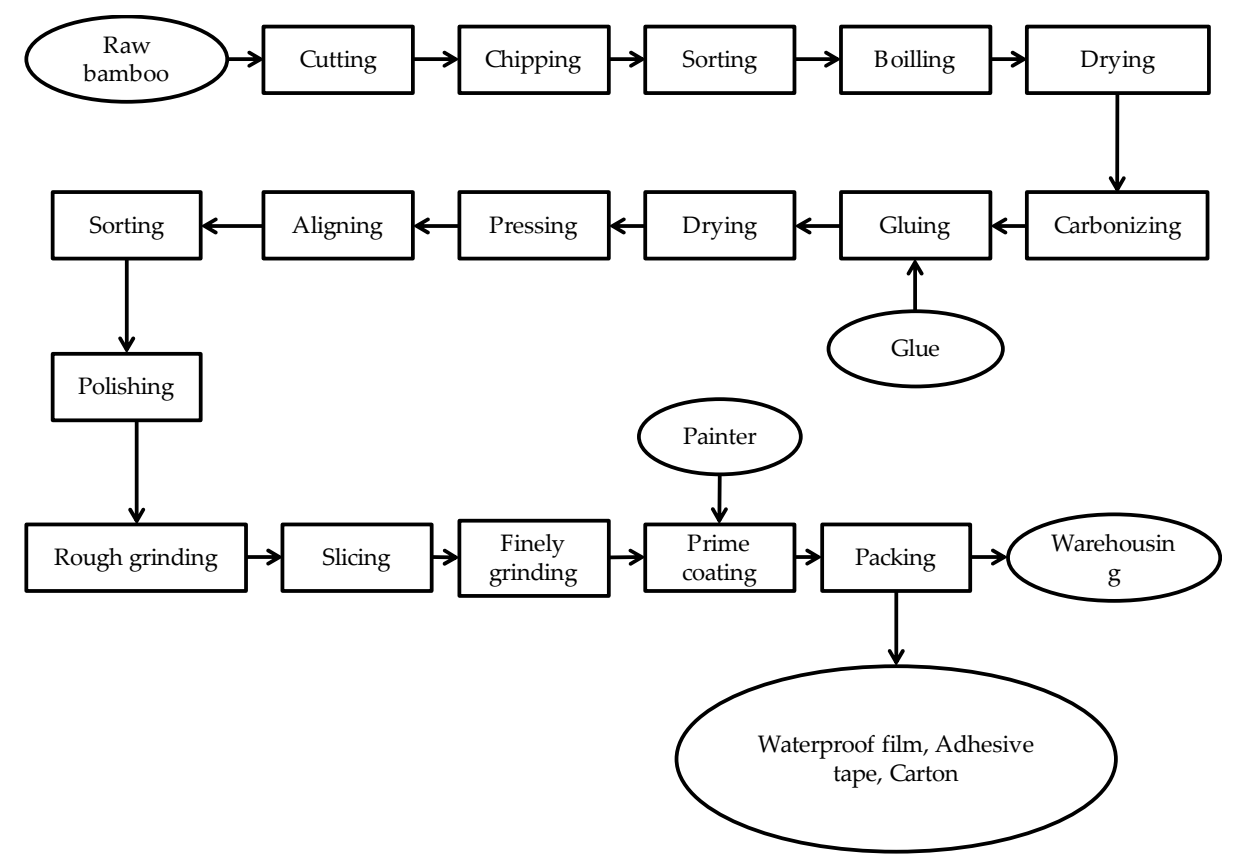

Figure 1. Procedure sketch for producing bamboo scrimber flooring. 
Transportations among workshops was excluded in this study due to a short distance and a small proportion of carbon emission compared to that of other parts of the production processes. Another potential carbon emission from fossil fuels excluded in the study was the application of mechanized lumbering. Unlike mature trees, bamboos have small diameters (diameter at breast height usually between 7 and $14 \mathrm{~cm}$ ) and hollow culms which makes them easy to cut with choppers. Typically, the harvesting of bamboo forest occurs on relatively gentle slopes (average of $25 \%$ ) where the distances from logging site to the loaders are relatively short. Furthermore, in most cases, the transport of cut bamboo to the loaders is not carried out by machines, but manually. Electric power used for transporting raw bamboos from logging plots to the foot of the hill was also excluded due to small proportion usage of this application in China.

\subsection{Sketch of the Production Process}

Based on factory investigation and face-to-face communication with technicians in Dasso Industrial Co. Ltd., all the required raw materials, processing activities, and procedures are depicted (Figure 1).

\subsection{Data Collection and Carbon Footprint Assessment}

First, we investigated and summarized all the procedures and materials applied for producing bamboo scrimber flooring. Then, we collected all the related initial-level data of carbon emission and storage sources, and these data were summarized into three types: energy flux, material flux, and carbon storage. The energy flux consisted of direct and indirect emission energy from fuel consumed during transportation and electrical power consumed during processing in the factory, respectively. The material flux included the indirect carbon emission embedded in the additive materials (e.g., glue, oil paint, and packaging carton). The carbon storage represented the carbon stored in the bamboo scrimber flooring (Table A1).

The carbon footprint of bamboo scrimber flooring was estimated by summarizing carbon emissions from bamboo flooring production processes, and subtracting the carbon stocks of bamboo products from the sum of emissions. Carbon emissions were calculated by multiplying the amount of material or energy costs during production processes with emission factors [25].

\subsubsection{Carbon Emission from Transportation}

The harvested bamboo culms were transported from Zixi, Jinxi, Nancheng, and Lichuang to Zixi, Jiangxi, in which the carbon emissions varied based on transportation. The distance and the carbon emission produced in transporting the semi-finished bamboo plank from Zixi to Dasso Industrial Co. Ltd. in Hangzhou, Zhejiang, were constant. Carbon emission from the transportation of the additive materials depended on the purchasing places and the corresponding distances. The transportation data was derived from the annual transportation reports of the companies.

Carbon emission from fossil fuels consumed in transporting $1 \mathrm{~m}^{3}$ material was calculated with formula (1):

$$
C_{1}=\sum_{i}^{n} P_{i} \times M_{i} \times D_{i} \times E F_{i}
$$

where $C_{1}$ is carbon emission from transportation $\left(\mathrm{kg} \mathrm{CO}_{2}\right.$ eq $\left.\mathrm{m}^{-3}\right), P_{i}$ is consumed fossil fuel per unit transported material $i$ per kilometer $\left(\mathrm{L} \mathrm{kg}^{-1} \mathrm{~km}^{-1}\right), M_{i}$ is weight of the transported material $i(\mathrm{~kg})$, $D_{i}$ is transportation distance $(\mathrm{km})$, and $E F_{i}$ is carbon emission factor for a specific fossil fuel $(\mathrm{kg} \mathrm{CO}$ eq $\mathrm{L}^{-1}$ ), i.e., 2.63 and $2.3 \mathrm{~kg} \mathrm{CO}_{2} \mathrm{eq} \mathrm{L}^{-1}$ for diesel and gasoline, respectively (IPCC EFDB).

\subsubsection{Carbon Emission from Production}

Producing bamboo scrimber flooring needs 19 processing procedures. To calculate the direct carbon emission from consumed electric energy during each processing procedure, we measured 
the involved machine's power, operation, and idle operation time. In each operation procedure, the measurement was conducted 3 times and ten samples were measured in each time. In each procedure, carbon emission from the consumed electric energy was calculated with formula (2):

$$
C_{2}=\sum_{i}^{n} P_{i} \times\left(0.75 T_{1 i}+0.2 T_{2 i}\right) \times E F_{i}
$$

where $C_{2}$ is carbon emission from the consumed electric energy $\left(\mathrm{kg} \mathrm{CO}_{2}\right.$ eq m$\left.{ }^{-3}\right), P_{i}$ is rated power of machine for $i$ th production procedure $\left(\mathrm{K}_{\mathrm{W}}\right), T_{1 i}$ is the operation time of machine for the $i$ th production procedure (s), $T_{2 i}$ is the idle operation time of machine for the $i$ th production procedure (s), 0.75 and 0.2 are coefficients of power consumption for operation and idle operation times, respectively, and $E F_{i}$ is the carbon emission factor of power consumption $\left(0.836 \mathrm{~kg} \mathrm{CO}_{2}\right.$ eq $\left.\mathrm{Kwh}^{-1}\right)$.

\subsubsection{Carbon Emission from Additive Materials}

Weights of the additive materials were derived by weighting the products before and after the processing or packaging. The corresponding carbon emission factors of the additive materials were collected from the database of carbon emission factors in IPCC database. Therefore, carbon emission from applied additives was calculated with formula (3):

$$
C_{3}=\sum_{i}^{n} P_{i} \times E F_{i}
$$

where $C_{3}$ is carbon emission from applied additives $\left(\mathrm{kg} \mathrm{CO}_{2} \mathrm{eq} \mathrm{m}{ }^{-3}\right), P_{i}$ is the amount of additive consumption in production $(\mathrm{kg}), E F_{i}$ is the carbon emission coefficient of the additive $\left(\mathrm{kg} \mathrm{kg}^{-1}\right)$, and $i$ is the source of carbon emission.

\subsubsection{Biomass Carbon Stock}

According to PAS 2050 specification, when a product contains biomass carbon that is stored in product for more than one year, this biomass carbon can be accounted in the assessment of GHG emission of the product. The weighted average of this carbon is treated as negative GHG emission. Due to the relatively long service life of the bamboo flooring, the effect of carbon stock was taken into account in the carbon footprint assessment of bamboo flooring. The biomass carbon stock was determined by multiplying the dry weight of the bamboo product by the carbon content of bamboo. The effect of carbon stock for bamboo scrimber flooring was calculated with formula (4):

$$
C_{4}=\frac{M \times 0.76 \times T_{0}}{100}
$$

where $C_{4}$ is the effect of carbon stock for bamboo scrimber flooring ( $\mathrm{kg} \mathrm{CO}_{2} \mathrm{eq}$ ), $M$ is carbon stock in $1 \mathrm{~m}^{3}$ of bamboo flooring ( $\mathrm{kg} \mathrm{CO} 2 \mathrm{eq}$ ) which derived from the amount of dry weight of bamboo flooring, carbon density and transfer ratio of carbon to $\mathrm{CO}_{2}(44 / 12), T_{0}$ is the theoretical service lifetime for a specific bamboo flooring, $\left(0.76 \times T_{0}\right) / 100$ is a weighted factor for carbon stock and only applicable for products with service life of $2-25$ years.

\subsection{Carbon Footprint of Bamboo Scrimber Flooring}

According to PAS 2050 specification, the carbon footprint of the bamboo scrimber flooring was derived by subtracting carbon stock in product from cumulated carbon emission from each production procedure (formula (5)):

$$
C=\sum_{i}^{n} C_{i}-C_{4}
$$


where $C$ is the carbon footprint of bamboo scrimber flooring $\left(\mathrm{kg} \mathrm{CO}_{2}\right.$ eq), $i$ is the source of carbon emission, $C_{i}$ is carbon emission per cubic meter for a specific carbon emission source $\left(\mathrm{kg} \mathrm{CO}_{2} \mathrm{eq}\right), C_{4}$ is the effect of carbon stock for bamboo scrimber flooring $\left(\mathrm{kg} \mathrm{CO}_{2} \mathrm{eq}\right)$.

\section{Results}

\subsection{Carbon Emission from Fossil Fuels during Transportation}

Carbon emission from transportation for producing $1 \mathrm{~m}^{3}$ bamboo scrimber flooring was 30.94 $\mathrm{kg} \mathrm{CO} 2$ eq (Table 1). Over $78 \%$ of the emission came from the transportation of semi-finished bamboo boards from the preliminary-processing factory to the deep-processing factory due to the long transportation distance, and almost $19 \%$ from the transportation of bamboo culms from the plantations to preliminary-processing factory due to the heaviest transported weight.

Table 1. Carbon emissions from transportation in producing one cubic meter of bamboo scrimber.

\begin{tabular}{|c|c|c|c|c|c|c|c|}
\hline $\begin{array}{c}\text { Transported } \\
\text { Material }\end{array}$ & Fuel & $\begin{array}{c}\text { Fuel } \\
\text { Consumption } \\
\left(\mathrm{L} \mathrm{t}^{-1} \mathrm{~km}^{-1}\right)\end{array}$ & $\begin{array}{c}\text { Distance } \\
(\mathbf{k m})\end{array}$ & $\begin{array}{c}\text { Weight } \\
\left(\mathrm{kg} \mathrm{m}^{-3}\right)\end{array}$ & $\begin{array}{l}\text { Carbon Emission } \\
\text { Factor of Fuel } \\
\quad\left(\mathrm{kg} \mathrm{L}^{-1}\right)\end{array}$ & $\begin{array}{c}\mathrm{CO}_{2} \text { Emission } \\
\text { Equivalent } \\
\left(\mathrm{kg} \mathrm{m}^{-3}\right)\end{array}$ & $\begin{array}{l}\text { Proportion of } \\
\mathrm{CO}_{2} \\
\text { Emission (\%) }\end{array}$ \\
\hline Bamboo culms & Diesel & 0.015 & 55 & 2686.09 & 2.63 & 5.83 & 18.83 \\
\hline Bamboo board & Diesel & 0.015 & 550 & 1115.27 & 2.63 & 24.20 & 78.20 \\
\hline Glue & Gasoline & 0.018 & 200 & 108.06 & 2.3 & 0.89 & 3.19 \\
\hline Oil paint & Gasoline & 0.015 & 200 & 1.47 & 2.3 & 0.01 & 0.03 \\
\hline Carton & Gasoline & 0.020 & 15 & 14.34 & 2.3 & 0.01 & 0.03 \\
\hline Total & & & & & & 30.94 & 100 \\
\hline
\end{tabular}

\subsection{Carbon Emission from the Power Supply for Production}

To produce $1 \mathrm{~m}^{3}$ bamboo scrimber flooring, the factories generated $143.37 \mathrm{~kg} \mathrm{CO}_{2}$ emission due to the consumed electric energy during production. Among these procedures, pressing and defibering procedures were the largest contributors, accounting for $24.25 \%$ and $17.27 \%$ of the $\mathrm{CO}_{2}$ emission, respectively (Table 2). 
Table 2. Carbon emissions from the production of $1 \mathrm{~m}^{3}$ bamboo scrimber flooring.

\begin{tabular}{|c|c|c|c|c|c|c|c|c|}
\hline Process & $\begin{array}{c}\text { Power } \\
(k w)\end{array}$ & $\begin{array}{c}\text { Plank } \\
\text { Operation }^{-1}\end{array}$ & $\begin{array}{l}\text { Operation } \\
\text { Time (s) }\end{array}$ & $\begin{array}{l}\text { Idle Time } \\
\text { (s) }\end{array}$ & $\begin{array}{l}\text { Power Consumption } \\
\left(K_{w h} \text { plank }^{-1}\right)\end{array}$ & $\underset{\left(\mathrm{kg} \mathrm{plank}^{-1}\right)}{\mathrm{CO}_{2} \text { Emission Equivalent }}$ & $\begin{array}{c}\mathrm{CO}_{2} \text { Emission Equivalent } \\
\left(\mathrm{kg} \mathrm{m}^{-3}\right)\end{array}$ & $\begin{array}{c}\text { Proportion of } \mathrm{CO}_{2} \\
\text { Emission (\%) }\end{array}$ \\
\hline Cutting & 4.5 & 1 & 13.3 & 33.3 & 0.0208 & 0.0174 & 3.4104 & 2.38 \\
\hline Chipping & 4 & 1 & 13.3 & 13.3 & 0.0140 & 0.0117 & 2.2932 & 1.60 \\
\hline Sorting & 6.3 & 1 & 66.6 & 33.3 & 0.0991 & 0.0829 & 16.2884 & 11.36 \\
\hline Boiling & 9.6 & 1 & 66.6 & 33.3 & 0.1510 & 0.1263 & 24.7548 & 17.27 \\
\hline Drying & 3 & 17,400 & 259,200 & / & 0.0093 & 0.0078 & 1.5288 & 1.07 \\
\hline Carbonizing & 1.5 & 14,545 & 46,800 & / & 0.0010 & 0.0008 & 0.1568 & 0.11 \\
\hline Gluing & / & / & / & / & / & / & / & / \\
\hline Drying & 3 & 14,800 & 12,600 & & 0.0005 & 0.0004 & 0.0784 & 0.05 \\
\hline Pressing & 31.8 & 3 & 80 & 60 & 0.2120 & 0.1774 & 34.7704 & 24.25 \\
\hline Aligning & 52 & 6 & 50 & 60 & 0.1192 & 0.0997 & 19.5412 & 13.63 \\
\hline Polishing & 22.5 & 1 & 10 & 3 & 0.0506 & 0.0424 & 8.3104 & 5.80 \\
\hline Rough grinding & 37 & 5 & 50 & 30 & 0.0894 & 0.0748 & 14.6608 & 10.23 \\
\hline Slicing & 10 & 1 & 6 & 3 & 0.0142 & 0.0119 & 2.3324 & 1.63 \\
\hline Finely grinding & 38 & 5 & 50 & 30 & 0.0918 & 0.0768 & 15.0528 & 10.50 \\
\hline Prime coating & 1.5 & 1 & 3 & 3 & 0.0012 & 0.0010 & 0.1960 & 0.14 \\
\hline Total & 1 & 1 & 1 & 1 & 0.87 & 0.73 & 143.37 & 100 \\
\hline
\end{tabular}

Note: carbon emission factor for electric power in east China is 0.8367 (Baseline Emission Factor of China Regional Power Grid). 


\subsection{Carbon Emission from Applied Additives}

Carbon emission from applied additives for producing $1 \mathrm{~m}^{3}$ bamboo scrimber flooring was $78.34 \mathrm{~kg} \mathrm{CO}_{2}$ eq, of which glue and carton account for $82.77 \%$ and $16.48 \%$, respectively (Table 3 ).

Table 3. Carbon footprint of additives in producing $1 \mathrm{~m}^{3}$ of bamboo scrimber flooring.

\begin{tabular}{|c|c|c|c|c|c|}
\hline Process & Additive & $\mathrm{EF}\left(\mathrm{kg} \mathrm{CO} \mathrm{eq} \mathrm{kg}^{-1}\right)$ & Weight (kg) & Carbon Emission (kg) & Ratio (\%) \\
\hline Gluing & Glue & 0.6 & 108.06 & 64.84 & 82.77 \\
\hline Painting & Paint & 0.6 & 0.98 & 0.59 & 0.75 \\
\hline Packing & Carton & 0.9 & 14.34 & 12.91 & 16.48 \\
\hline Total & & & & 78.34 & 100 \\
\hline
\end{tabular}

\subsection{Biomass Carbon Stocks}

Based on the $886.49 \mathrm{~kg} \mathrm{~m}^{-3}$ dry weight per 1 cubic meter of the bamboo scrimber flooring, the $54.15 \%$ carbon content of bamboo [26], the $44 / 12$ carbon transfer ratio from carbon to $\mathrm{CO}_{2}$, and the 20-year service life of bamboo scrimber flooring, the biomass carbon stock of $1 \mathrm{~m}^{3}$ bamboo scrimber flooring was $267.54 \mathrm{~kg} \mathrm{CO}$ eq.

\subsection{Carbon Footprint Assessment for Produce $1 \mathrm{~m}^{3}$ of Bamboo Scrimber Flooring}

To produce $1 \mathrm{~m}^{3}$ bamboo scrimber flooring, carbon emissions were $30.94 \mathrm{~kg} \mathrm{CO}_{2}$ eq, $143.37 \mathrm{~kg}$ $\mathrm{CO}_{2}$ eq, and $78.34 \mathrm{~kg} \mathrm{CO}_{2}$ eq from fossil fuels during transportation, consumption of energy during the production process, and additives, respectively. Subtracting the $267.54 \mathrm{~kg} \mathrm{CO}_{2} \mathrm{eq} \mathrm{m}^{-3}$ carbon stock from the total $252.65 \mathrm{~kg} \mathrm{CO}_{2}$ eq m${ }^{-3}$ carbon emission resulted in a $-14.89 \mathrm{~kg} \mathrm{CO}_{2}$ eq carbon footprint for producing $1 \mathrm{~m}^{3}$ bamboo scrimber flooring, indicating that this bamboo product is a net carbon sink (Figure 2) and this amount of carbon can be stored for at least 20 years in bamboo scrimber flooring.

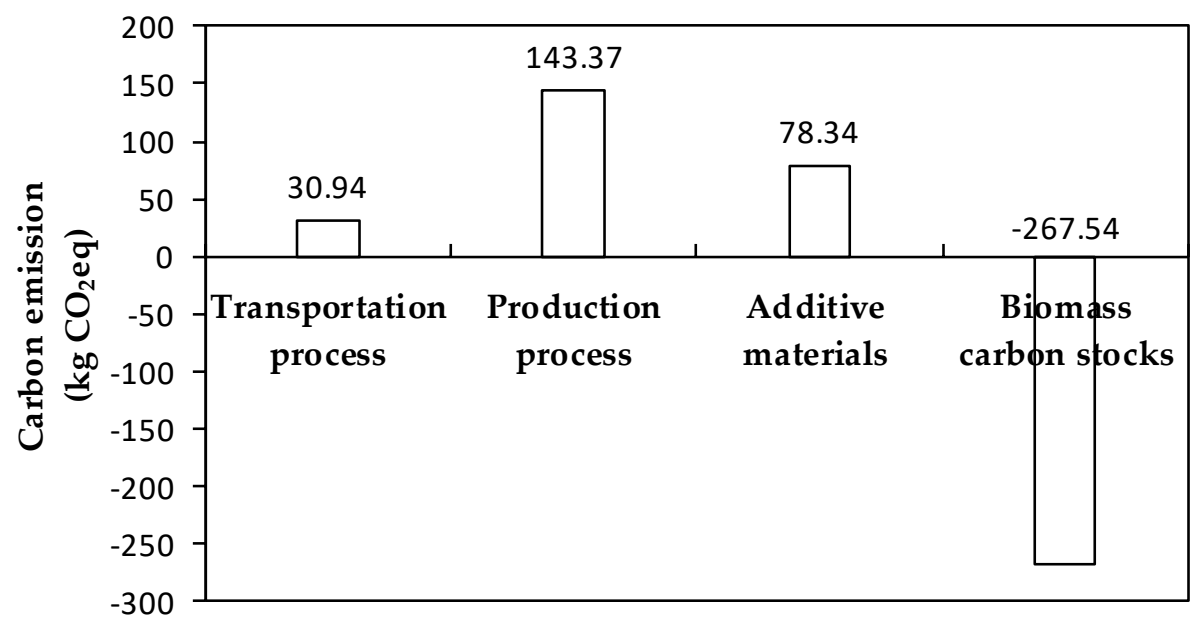

Figure 2. The composition of the carbon footprint for producing $1 \mathrm{~m}^{3}$ bamboo scrimber flooring.

\section{Discussion}

\subsection{Analysis of Carbon Emission Reduction Potentials}

Based on life cycle assessment and input-output analysis, we made layer decomposition for the carbon footprint of bamboo scrimber flooring. With the layer decomposition, we built an analysis framework for reducing the carbon emission of the product (Figure 3). The framework consists of two parts: carbon emission with four layers, and carbon storage with one layer. The carbon emission 
part represented the carbon emission sources and their corresponding priority rankings and potential approaches to reduce emissions.

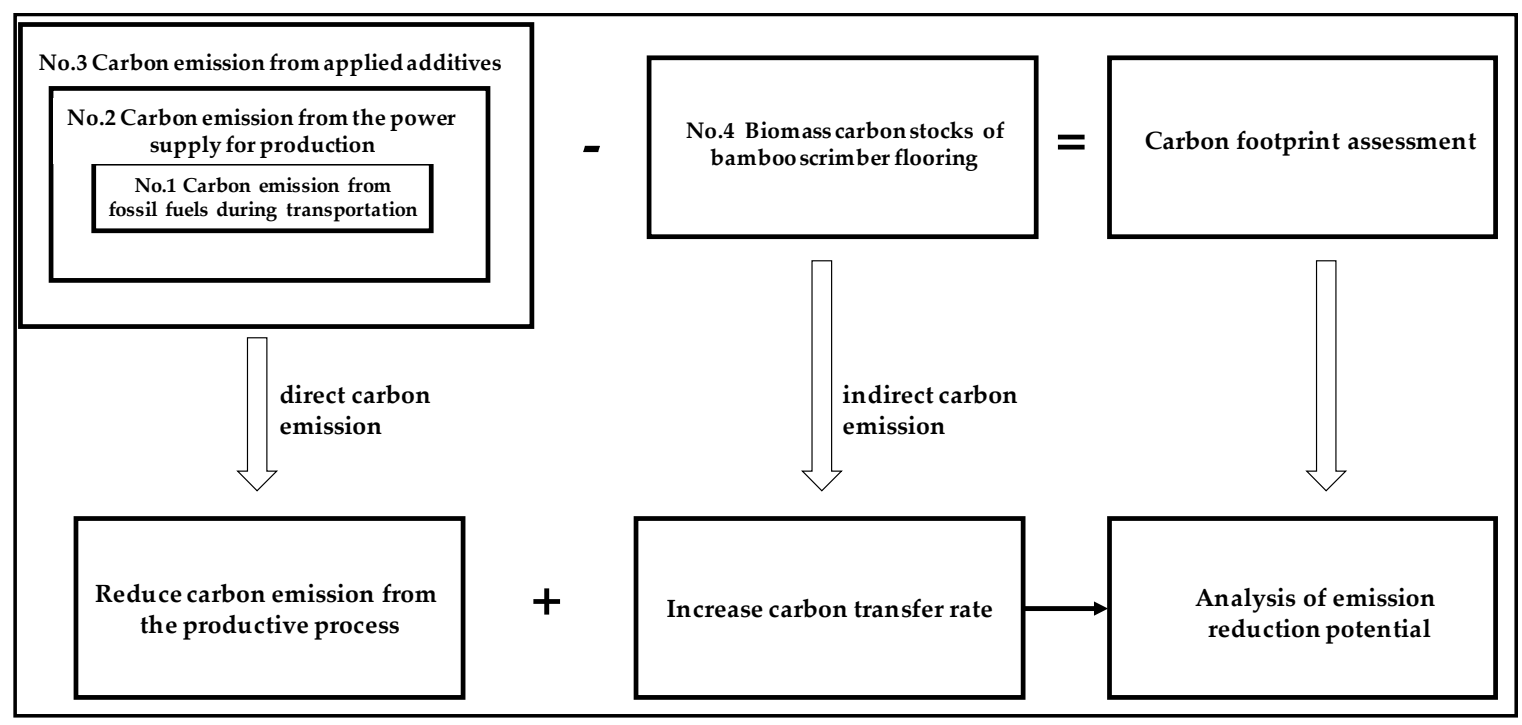

Figure 3. An analysis framework for the decomposed carbon footprint of bamboo scrimber flooring.

\subsubsection{Carbon Emission from Transportation}

Transportation of raw bamboo culms, semi-finished bamboo board, and additive materials consumed fuel and thus led to direct carbon emission. In this study, transportation distance was one of the most important factors influencing the carbon footprint of bamboo flooring. To gain a maximum profit with cheaper raw materials, the studied enterprise bought the bamboo culms and bamboo board from a relatively distant location. The longer distance resulted in a large carbon footprint. Therefore, purchasing raw materials from nearby sources is a potential means to reduce emissions. Lowering energy consumption and emission per unit product by optimizing transportation mode, e.g., replacing road transportation with railway transportation is another possible way to reduce carbon emission from transportation.

\subsubsection{Carbon Emission during the Production Processes}

Carbon emissions during production processes resulted from consumption of electric energy which was mostly produced from coals in China. Carbon emission during the production was the largest part of the total carbon emission (55.15\%). Pressing, defibering, and sorting accounted for $24.24 \%, 17.28 \%, 13.63 \%$ of the total carbon emission of production processes, respectively. Power rates of the applied machines were fixed, thus the possibilities to reduce carbon emission using the existing machinery would be limited. In the high power-consumption procedures, e.g., defibering, replacing machines with more efficient ones is a possible way to reduce carbon emission. In addition, operation and idle times were also important factors influencing the emission. To produce $1 \mathrm{~m}^{3}$ bamboo scrimber flooring, operation times for pressing, sorting, and polishing were $80 \mathrm{~s}, 50 \mathrm{~s}$, and $100 \mathrm{~s}$, and the idle operation time was $60 \mathrm{~s}$ in each step (Table 2). Reducing idle operation time could be realized by improving workers' efficiency. The whole production process involved more than a dozen procedures, a number of which might be reduced by innovative techniques or production process designs.

\subsubsection{Carbon Emission from Additive Materials}

Embodied carbon in the entire supply chain is mainly inputted materials in the production process. In this study, the applied additives include glue, oil paint, and cartons. To produce the bamboo scrimber flooring, bamboo culms are defibered into bamboo fibers that are pressed together using a large amount of glue, which makes the board resistant to pressure and moisture. The glue was 
the largest source of carbon emission in the production. Therefore, choosing eco-friendly glues with smaller carbon footprints and reducing the applied amounts would result in lower total emissions. At the same time, within the constraints of not affecting the quality of the product, achieving lower carbon emissions might be feasible by reducing the gluing temperature and controlling the amount used. Application of oil paint led to minimal carbon emission. Re-designing the packages according to the product specifications is a possible way to reduce emissions from packaging.

\subsubsection{Effect of Carbon Stock in Bamboo Products}

Through the production processes of bamboo flooring, carbon in the bamboo forest pool was transferred into product pool where it will stay for 2 decades. Carbon stock in bamboo products can be influenced by the carbon transfer rate: the higher the carbon transfer ratio during the production process, the larger the carbon stocks in the bamboo products. Boiling and carbonizing procedures result in relatively larger carbon loss ratios than other procedures, and thus improving these techniques to increase the carbon transfer ratios would reduce the carbon footprint of bamboo flooring. In addition, larger carbon transfer ratio may be achieved by using bamboos of suitable sizes. Also, increasing the service life of flooring by increasing the hardness and density and improving the rot resistance, moisture tolerance, and non-deform characteristics of the flooring is another possible way to mitigate carbon emission.

\subsection{The Implication for Bamboo Forests Carbon Sequestration}

Former studies on bamboos have revealed carbon cycles and carbon stocks in bamboo forest ecosystems [27-36], while carbon footprints of bamboo products received much less attention [37]. Due to the complexity of the production processes, existing carbon footprint researches mainly focused on direct carbon emissions (i.e., fossil fuels or electricity) and ignored indirect carbon emissions (i.e., additives). We calculated the carbon footprint of bamboo flooring, taking into accounts both transportation and production processes and considering both direct and indirect carbon emissions, by using initial-level data in each stage of transportation and production processes.

Estimated carbon footprint of $1 \mathrm{~m}^{3}$ bamboo scrimber flooring $\left(-14.89 \mathrm{~kg} \mathrm{CO}_{2}\right.$ eq) showed that the studied bamboo flooring is a net carbon sink which can be stored in the products for at least 20 years. Compared to other wood products (e.g., cork, eucalypt), bamboo scrimber flooring is less efficient in terms of net carbon sink per unit volume of product. However, bamboo forests can be logged every two years and, thus, a relatively constant supply of bamboo can be supplied compared to other tree species that require longer harvesting cycles. Therefore, our study on bamboo flooring will enrich studies of wood products and provide more scientific basis for estimating carbon footprint of bamboo products.

This study expanded the bamboo forest carbon cycle and carbon transfer research from natural ecosystems to the production chain of bamboo products. Our results provide a scientific basis for estimating carbon stock transferred from culms to bamboo products, and thereby expand the research boundary of bamboo forest carbon sequestration and revealed the carbon sequestration capacity of bamboo forest from the perspective of the entire life cycle.

\subsection{Uncertainty Analysis}

There are several uncertainty aspects in assessments of carbon footprints of a bamboo products (e.g., transportation distance, manual operation of the machine during production processes, additives, etc.). We investigated the whole production processes to minimize the uncertainty of carbon footprints, which helped to accurately calculate carbon footprints and its reliability. Three aspects were considered in this study to improve the calculation.

(1) Transportation. There is a great uncertainty in transportation distance due to different logging places for raw bamboos. Therefore, we used the annual mean transportation distance to calculate 
carbon emissions from transportation. Transportation for additives was ignored in this study due to the limited quantity of the substrates.

(2) Production processes. Manual operation of machinery leads to large uncertainty in assessing the carbon footprint. This is mainly because of the relatively large differences in workers' efficiency. To minimize the assessment error, we increased samples in each production process (i.e., in each operation procedure, the measurement was conducted three times and ten samples were measured each time).

(3) Additives. In this study, we didn't measure carbon footprints of additives from their production processes. Instead, we calculated carbon emissions of additives with the existing carbon emission factors from the IPCC database. This may introduce biases in assessing carbon footprints of additives.

\section{Conclusions}

To our knowledge, this is the first empirical study to evaluate the carbon emission and carbon stocks of bamboo scrimber flooring in each step of the whole production processes, including transportation, production, and packing. We collected the initial-level data and used the B2B evaluation method to assess the carbon emission and stocks of bamboo scrimber flooring. Our results showed that carbon emission from producing $1 \mathrm{~m}^{3}$ bamboo scrimber flooring was $30.94 \mathrm{~kg} \mathrm{CO}_{2}$ eq, $143.37 \mathrm{~kg} \mathrm{CO}$ eq, and $78.34 \mathrm{~kg} \mathrm{CO}_{2}$ eq from fossil fuels during transportation, consumption of power energy during the production process, and additives, respectively. By subtracting the $267.54 \mathrm{~kg} \mathrm{CO}_{2}$ eq carbon stock from the emissions, we found that the final carbon footprint for producing $1 \mathrm{~m}^{3}$ bamboo scrimber flooring was $-14.89 \mathrm{~kg} \mathrm{CO}_{2}$ eq. Therefore, this study demonstrated that bamboo scrimber flooring is a negative carbon emission product that sequesters carbon for at least 20 years. We estimated the size of carbon stocks in bamboo scrimber flooring and extended studies of bamboo forest carbon cycling to products, which provides a perspective of full life dynamics of carbon cycling for bamboo forest ecosystems.

Author Contributions: The analysis was performed by L.G. All authors contributed with ideas, writing, and discussion.

Acknowledgments: This study was supported by the National Social Science Fund of China (grant number: 18BGL174), the Central Fiscal Forestry Science and Technology Extension Demonstration Project (grant number: 2017TS07), the China Green Carbon Sink Foundation Project (grant number: H20170049). We wish to acknowledge Petri Penttinen, Zhejiang A\&F University, for his help in revising our manuscript. We thank the editor and anonymous reviewers for their contribution to the peer review of our work.

Conflicts of Interest: The authors declare no conflict of interest. 


\section{Appendix A}

Table A1. Description of the dataset used for estimating the carbon footprint of bamboo scrimber flooring.

\begin{tabular}{|c|c|c|c|}
\hline Type of Dataset & Investigated Objects & Measurable Factors & Data Sources \\
\hline Fuel energy & $\begin{array}{l}\text { Gasoline and diesel used for } \\
\text { transportation }\end{array}$ & $\begin{array}{l}\text { Weight of gasoline or diesel for transporting per } 1 \mathrm{~kg} \\
\text { material per } 100 \mathrm{~km} \text { distance }\left(\mathrm{kg} \mathrm{km}^{-1}\right) \text {; } \\
\text { weight of transported materials }(\mathrm{kg}) ; \\
\text { transportation distance }(\mathrm{kg}) \text {; } \\
\text { carbon emission factors for gasoline and diesel }\end{array}$ & $\begin{array}{l}\text { Carbon emission factors for gasoline and diesel } \\
\text { refer to IPCC EFDB (https: } \\
\text { //www.ipcc-nggip.iges.or.jp / EFDB / main.php), } \\
\text { and other measurable factors were provided by } \\
\text { Dasso company }\end{array}$ \\
\hline Electric energy & $\begin{array}{l}\text { Electric energy consumed during } \\
\text { production processes }\end{array}$ & $\begin{array}{l}\text { Rated power of machine; } \\
\text { idle and operation time of applied machines; } \\
\text { carbon emission factors for electricity }\end{array}$ & $\begin{array}{l}\text { Carbon emission factors for electricity refer to Eas } \\
\text { China Power Grid of National Development and } \\
\text { Reform Commission, and other measurable } \\
\text { factors were investigated by authors. }\end{array}$ \\
\hline $\begin{array}{l}\text { Carbon emission from } \\
\text { applied additives }\end{array}$ & $\begin{array}{l}\text { Glue, oil paint, and cartoon, etc. } \\
\text { used during production } \\
\text { processes. }\end{array}$ & $\begin{array}{l}\text { The quantity of applied additives for producing } 1 \mathrm{~m}^{3} \\
\text { of bamboo flooring; } \\
\text { carbon emission factor for each additive }\end{array}$ & $\begin{array}{l}\text { Quantity of applied additives was measured. } \\
\text { Carbon emission factors for additives refer to } \\
\text { IPCC EFDB. }\end{array}$ \\
\hline $\begin{array}{l}\text { Biomass carbon stock } \\
\text { in products }\end{array}$ & $\begin{array}{l}\text { Carbon stock in bamboo scrimber } \\
\text { flooring transferred from raw } \\
\text { bamboo culm }\end{array}$ & $\begin{array}{l}\text { Carbon transfer ratio during production processes; } \\
\text { dry weight of the bamboo flooring; } \\
\text { carbon density. }\end{array}$ & $\begin{array}{l}\text { Carbon stock of bamboo flooring was measured, } \\
\text { and carbon transfer ratio was derived from carbon } \\
\text { stocks of bamboo flooring and raw bamboo culm } \\
\text { Carbon density of raw bamboo culm refers to } \\
\text { Zhou (2006). }\end{array}$ \\
\hline
\end{tabular}




\section{References}

1. Brito de Figueirêdo, M.C.; Kroeze, C.; Potting, J.; da Silva Barros, V.; Sousa de Aragão, F.A.; Gondim, R.S.; de Lima Santos, T.; de Boer, I.J.M. The carbon footprint of exported brazilian yellow melon. J. Clean. Prod. 2013, 47, 404-414. [CrossRef]

2. Pattara, C.; Raggi, A.; Cichelli, A. Life cycle assessment and carbon footprint in the wine supply-chain. Environ. Manag. 2012, 49, 1247-1258. [CrossRef] [PubMed]

3. Boguski, T.K. Life cycle carbon footprint of the national geographic magazine. Int. J. Life Cycle Assess. 2010, 15, 635-643. [CrossRef]

4. Akbari, S.; Nurul Habib, K. Oil vulnerability in the greater toronto area: Impacts of high fuel prices on urban form and environment. Int. J. Environ. Sci. Technol. 2014, 11, 2347-2358. [CrossRef]

5. Li, J.; Shi, H. Research on improvement of product carbon footprint measurement system based on internet of things (in Chinese). Sci. Technol. Prog. Policy 2014, 4, 6-10.

6. Quinteiro, P.; Araújo, A.; Oliveira, B.; Dias, A.C.; Arroja, L. The carbon footprint and energy consumption of a commercially produced earthenware ceramic piece. J. Eur. Ceram. Soc. 2012, 32, 2087-2094. [CrossRef]

7. Demertzi, M.; Paulo, J.A.; Arroja, L.; Dias, A.C. A carbon footprint simulation model for the cork oak sector. Sci. Total Environ. 2016, 566-567, 499-511. [CrossRef] [PubMed]

8. Demertzi, M.; Paulo, J.A.; Faias, S.P.; Arroja, L.; Dias, A.C. Evaluating the carbon footprint of the cork sector with a dynamic approach including biogenic carbon flows. Int. J. Life Cycle Assess. 2018, 23, 1448-1459. [CrossRef]

9. Dias, A.C.; Arroja, L. Comparison of methodologies for estimating the carbon footprint-Case study of office paper. J. Clean. Prod. 2012, 24, 30-35. [CrossRef]

10. Salahuddin, M.; Alam, K.; Ozturk, I. Is rapid growth in internet usage environmentally sustainable for Australia? An empirical investigation. Environ. Sci. Pollut. Res. 2016, 23, 4700-4713. [CrossRef] [PubMed]

11. Zhang, Q.; Zheng, D.; Xu, X.S. Factor decomposition study on the change of ecological pressure of China's energy carbon footprint. Arid Area Resour. Environ. 2015, 29, 41-46.

12. Cornejo, P.K.; Zhang, Q.; Mihelcic, J.R. Quantifying benefits of resource recovery from sanitation provision in a developing world setting. J. Environ. Manag. 2013, 131, 7-15. [CrossRef] [PubMed]

13. Weinzettel, J.; Steen-Olsen, K.; Hertwich, E.G.; Borucke, M.; Galli, A. Ecological footprint of nations: Comparison of process analysis, and standard and hybrid multiregional input-output analysis. Ecol. Econ. 2014, 101, 115-126. [CrossRef]

14. Gratani, L.; Crescente, M.L.; Fabrini, G.; Digiulio, E. Growth pattern and photosynthetic activity of different bamboo species growing in the botanical garden of Rome. Flora 2008, 203, 77-84. [CrossRef]

15. Li, Z.; Kobayashi, M. Plantation future of bamboo in China. J. For. Res. 2004, 15, 233-242. [CrossRef]

16. FAO. Global Forest Resources Assessment 2010: Main Report; Food and Agriculture Organization of the United Nations: Rome, Italy, 2010.

17. SFAPRC. Forest Resources in China-The 8th National Forest Inventory; State Forestry Administration: Beijing, China, 2015.

18. Song, X.Z.; Zhou, G.; Jiang, H.; Yu, S.Q.; Fu, J.H.; Li, W.Z.; Wang, W.F.; Ma, Z.H.; Peng, C.H. Carbon sequestration by Chinese bamboo forests, and their ecological benefits: Assessment of potential, problems, and future challenges. Environ. Rev. 2011, 19, 418-428. [CrossRef]

19. Yen, T.M. Comparing aboveground structure and aboveground carbon storage of an age series of moso bamboo forests subjected to different management strategies. J. For. Res. 2015, 20, 1-8. [CrossRef]

20. Yen, T.M. Culm height development, biomass accumulation and carbon storage in an initial growth stage for a fast-growing moso bamboo (Phyllostachy pubescens). Bot. Stud. 2016, 57, 10. [CrossRef] [PubMed]

21. Yen, T.M.; Lee, J.S. Comparing aboveground carbon sequestration between moso bamboo (Phyllostachys heterocycla) and china fir (Cunninghamia lanceolata) forests based on the allometric model. For. Ecol. Manag. 2011, 261, 995-1002. [CrossRef]

22. Eastday.com. In 2015, the Output Value of China's Bamboo Industry Was Nearly 200 Billion Yuan. 2016. Available online: https:/ finance.sina.cn/stock/jdts/2016-10-13/detail-ifxwvpqh7348217.d.html (accessed on 13 October 2016). 
23. Lobovikov, M.; Paudel, S.; Piazza, M. World Bamboo Resources: A Thematic Study Prepared in the Framework of the Global Forest Resources Assessment 2005; Food and Agriculture Organization of the United Nation: Rome, Italy, 2007; pp. 1-81.

24. Network, C.F. Bamboo Flooring Market Analysis: 60\% to 70\% of Production Exports. 2017. Available online: http:/ / www.chinafloor.cn/ (accessed on 21 November 2017).

25. The Intergovernmental Panel on Climate Change. EFDB Emission Factor Database. 2016. Available online: https:/ / www.ipcc-nggip.iges.or.jp/EFDB/main.php (accessed on 20 September 2016).

26. Zhou, G.M. Carbon Storage, Fixation and Distribution in Moso Bamboo (Phyllostachy pubescens) Stands Ecosystem. Ph.D. Thesis, Zhejiang University, Hangzhou, China, 1 April 2006.

27. Du, H.Q.; Zhou, G.M.; Ge, H.L.; Fan, W.Y.; Xu, X.J.; Fan, W.L.; Shi, Y.J. Satellite-based carbon stock estimation for bamboo forest with a non-linear partial least square regression technique. Int. J. Remote Sens. 2012, 33, 1917-1933. [CrossRef]

28. Han, N.; Du, H.; Zhou, G.; Xu, X.; Cui, R.; Gu, C. Spatiotemporal heterogeneity of moso bamboo aboveground carbon storage with landsat thematic mapper images: A case study from Anji County, China. Int. J. Remote Sens. 2013, 34, 4917-4932. [CrossRef]

29. Du, H.Q.; Zhou, G.M.; Fan, W.Y.; Ge, H.L.; Xu, X.J.; Shi, Y.J.; Fan, W.L. Spatial heterogeneity and carbon contribution of aboveground biomass of moso bamboo by using geostatistical theory. Plant Ecol. 2009, 207, 131-139. [CrossRef]

30. Xu, X.J.; Du, H.Q.; Zhou, G.M.; Ge, H.L.; Shi, Y.J.; Zhou, Y.F.; Fan, W.L.; Fan, W.Y. Estimation of aboveground carbon stock of moso bamboo (Phyllostachys heterocycla var. Pubescens) forest with a landsat thematic mapper image. Int. J. Remote Sens. 2011, 32, 1431-1448. [CrossRef]

31. Shang, Z.; Zhou, G.; Du, H.; Xu, X.; Shi, Y.; Lü, Y.; Zhou, Y.; Gu, C. Moso bamboo forest extraction and aboveground carbon storage estimation based on multi-source remotely sensed images. Int. J. Remote Sens. 2013, 34, 5351-5368. [CrossRef]

32. Li, X.J.; Mao, F.J.; Du, H.Q.; Zhou, G.M.; Xu, X.J.; Han, N.; Sun, S.B.; Gao, G.L.; Chen, L. Assimilating leaf area index of three typical types of subtropical forest in china from modis time series data based on the integrated ensemble kalman filter and prosail model. ISPRS J. Photogram. Remote Sens. 2017, 126, 68-78. [CrossRef]

33. Xu, X.J.; Du, H.Q.; Zhou, G.M.; Mao, F.J.; Li, P.H.; Fan, W.L.; Zhu, D.E. A method for daily global solar radiation estimation from two instantaneous values using modis atmospheric products. Energy 2016, 111, 117-125. [CrossRef]

34. Song, X.Z.; Chen, X.F.; Zhou, G.M.; Jiang, H.; Peng, C.H. Observed high and persistent carbon uptake by moso bamboo forests and its response to environmental drivers. Agric. For. Meteorol. 2017, 247, 467-475. [CrossRef]

35. Xu, X.J.; Zhou, G.M.; Liu, S.G.; Du, H.Q.; Mo, L.F.; Shi, Y.J.; Jiang, H.; Zhou, Y.F.; Liu, E.B. Implications of ice storm damages on the water and carbon cycle of bamboo forests in southeastern China. Agric. For. Meteorol. 2013, 177, 35-45. [CrossRef]

36. Xu, X.J.; Du, H.Q.; Zhou, G.M.; Li, P.H.; Shi, Y.J.; Zhou, Y.F. Eddy covariance analysis of the implication of drought on the carbon fluxes of moso bamboo forest in southeastern china. Trees 2016, 30, 1807-1820. [CrossRef]

37. Van der Lugt, P.; Vogtlander, J. The Environmental Impact of Industrial Bamboo Products—Life-Cycle Assessment and Carbon Sequestration; Report Number: INBAR Technical Report 35; International Network for Bamboo and Rattan (INBAR): Beijing, China, 2015.

(C) 2019 by the authors. Licensee MDPI, Basel, Switzerland. This article is an open access article distributed under the terms and conditions of the Creative Commons Attribution (CC BY) license (http://creativecommons.org/licenses/by/4.0/). 